\title{
ANALISIS PENGARUH PENGUKURAN KINERJA KEUANGAN DALAM MEMPREDIKSI RETURN SAHAM PADA PERUSAHAAN MANUFAKTUR YANG TERDAFTAR DI BURSA EFEK INDONESIA
}

\author{
Barbara Gunawan* \\ Rizki Putri Hardyani \\ Universitas Muhammadiyah Yogyakarta \\ *barbaragunawan@yahoo.co.id
}

INTISARI

Tujuan penelitian ini adalah untuk melakukan analisis terhadap pengaruh pengukuran kinerja keuangan dengan menggunakan rasio keuangan yaitu rasio profitabilitas, likuiditas, aktivitas, leverage dan rasio Market Value (nilai pasar) untuk memprediksi return saham pada perusahaan manufaktur yang terdaftar di Bursa Efek Indonesia.

Populasi yang digunakan dalam penelitian ini adalah perusahaan manufaktur yang terdaftar di Bursa Efek Indonesia selama tahun 2009 sampai dengan 2012. Pengambilan sampel perusahaan dalam penelitian ini dilakukan dengan metode purposive sampling yaitu dengan didasarkan pada perusahaan manufaktur yang menerbitkan laporan keuangan resmi dan informasi harga saham selama periode pengamatan. Data tersebut diperoleh dari Indonesia Stock Exchange (IDX), Yahoo Finance, dan situs resmi perusahaan. Jumlah sampel yang digunakan dalam penelitian ini sebanyak 95 perusahaan dan menggunakan metode analisis regressi berganda dengan bantuan pengolahan data SPSS 15,0.

Hasil penelitian ini memberikan kesimpulan bahwa variabel rasio keuangan secara bersama-sama memiliki pengaruh yang signifikan terhadap return saham. Hasil pengujian secara partial pada variabel rasio ROA, ROE, NPM, Current Ratio, TAT, DER, DAR, MBV diperoleh bahwa hanya variabel ROA dan ROE saja yang memiliki pengaruh positif signifikan terhadap return saham.

Kata Kunci: Rasio Profitabilitas, Likuiditas, Aktivitas, Leverage, Rasio Market Value, dan Return saham

\section{PENDAHULUAN}

Pada Bursa Efek Indonesia saham yang diperdagangkan terdiri dari beberapa macam sektor, salah satunya yaitu sektor perusahaan manufaktur. Pertumbuhan perusahaan manufaktur ini merupakan salah satu peranan penting dalam pertumbuhan perekonomian di Indonesia. Fakta yang terlihat bahwa kondisi pertumbuhan industri manufaktur di BEI sejak tahun 2007 hingga 2009 terus mengalami penurunan, hal ini terlihat dalam data Badan Pusat Statistik (BPS) bahwa tahun 2007 tingkat pertumbuhan industri manufaktur tercatat sebesar $5,57 \%$ dan mengalami penurunan di tahun 2008 menjadi $3,01 \%$. Angka pertumbuhan tersebut sangat mengalami penurunan di tahun 2009 yaitu pertumbuhannya hanya tercatat sebesar 1,34\%. Namun pada tahun berikutnya, kondisi pertumbuhan industri di Indonesia mulai mengalami peningkatan meskipun krisis global pada tahun 2010 sedang melanda hampir seluruh negara Eropa dan Amerika. Adanya peningkatan pertumbuhan industri tersebut terlihat dari data BPS bahwa pada tahun 2010 sampai dengan 2011 pertumbuhan industri tercatat sebesar $4,45 \%$ dan 5,56\%. Kemudian pada tahun 2012 pertumbuhan industri sedikit mengalami penurunan yaitu tercatat sebesar $4,12 \%$ (www.bps.go.id diakses pada tanggal 19 Mei 2013).

Tingkat pertumbuhan industri manufaktur dalam pasar modal menjadi salah satu perhatian penting oleh para investor (pemegang saham) terutama pada kinerja perusahaan dalam menghasilkan return yang akan diperoleh. Kinerja suatu perusahaan dapat dinilai oleh para investor melalui 
kinerja keuangannya. Penilaian kinerja keuangan ini dapat ditunjukkan dengan melakukan analisis pada rasio keuangan untuk menggambarkan sejauh mana penilaian mengenai kinerja keuangan dapat memengaruhi reaksi para investor yang terlihat dari return saham yang diperoleh. Return saham merupakan imbalan yang diperoleh investor atas investasi yang diberikan kepada perusahaan (Robert Ang, dalam Utomo, 2007). Return dibedakan menjadi dua, yaitu return yang telah terjadi (capital gain) yang dihitung berdasarkan pada data historisnya, dan return yang diharapkan (dividend yield) yang akan diperoleh investor di masa datang. (Halim, 2005).

Berdasarkan laporan keuangan perusahaan, dapat diketahui bahwa rasio keuangan biasa digunakan sebagai alat pengukuran kinerja keuangan perusahaan. Menurut Bringham dan Houston (2010) terdapat lima macam rasio keuangan yang mampu untuk memprediksi return saham yaitu rasio profitabilitas, rasio leverage, rasio likuiditas, rasio aktivitas dan rasio nilai pasar (Market Value). Kelima rasio tersebut dapat bermanfaat bagi investor sebagai sumber informasi dan dasar analisis untuk penentuan return saham yang akan diperoleh, karena seorang investor perlu untuk memiliki informasi yang akurat dalam memeroleh gambaran kondisi perusahaan secara menyeluruh. Manfaat dari rasio keuangan tersebut bagi investor antara lain, (1) rasio profitabilitas yang berfungsi untuk menilai kinerja perusahaan dalam menghasilkan keuntungan. Rasio profitabilitas ini meliputi ROA, ROE atau NPM. Bagi para investor kemampuan perusahaan dalam menghasilkan laba merupakan suatu hal yang sangat penting karena pada akhirnya hal itu akan berpengaruh terhadap return saham yang akan diperoleh investor (widyawati, 2012). (2) Rasio Likuiditas memiliki manfaat untuk menilai kinerja perusahaan dalam memenuhi kewajiban lancarnya, menurut Prihantini (2009) informasi dari rasio ini dapat memengaruhi tingkat kepercayaan bagi para investor.
Selanjutnya, (3) rasio aktivitas juga memiliki manfaat bagi investor sebagai dasar untuk melihat kinerja perusahaan dalam menghasilkan penjualan yang diharapkan dapat berpengaruh terhadap return yang diperoleh, salah satu proksi yang dapat digunakan yaitu Total Asset Turnover. (4) Rasio leverage berfungsi sebagai pengukur kinerja perusahaan dalam pemenuhuan kewajiban (hutang) yang dimiliki kepada pihak kreditur sebagai dasar bagi investor untuk mengetahui prospek keberlangsungan perusahaan. Proksi dari rasio ini yaitu $D E R$ dan $D A R$. Rasio yang terakhir yaitu (5) rasio market value yang memiliki manfaat untuk mengukur pergerakan harga saham perusahaan dimana return saham yang diperoleh diharapkan akan mengikuti pergerakan dari harga saham tersebut.

Namun, analisis rasio keuangan sebagai wujud dalam kinerja perusahaan berdasarkan pada bukti empiris masih menunjukkan hasil yang bervariasi sebagai dasar dalam menentukan return saham. Hal ini terlihat dari hasil penelitian terdahulu yaitu Hidayat (2009), Saputra (2012) dan Oktanugroho (2012) bahwa ROE tidak berpengaruh signifikan terhadap return saham. Penelitian tersebut tidak konsisten dengan penelitian yang dilakukan oleh Widodo (2007), Widyawati (2012) dan Fidhayatin (2012) yang menyatakan bahwa ROE memiliki pengaruh yang signifikan terhadap return saham pada perusahaan.

Hal lainnya juga terlihat dari penelitian yang dilakukan oleh Ulupui (2005), Prihantini (2009) dan Oktanugroho (2012) yang memeroleh hasil bahwa ROA memiliki pengaruh yang signifikan terhadap return saham pada perusahaan. Namun, penelitian tersebut tidak sejalan dengan penelitian yang dilakukan oleh Kusumo (2011), Widyawati (2012) dan Nurhikmah (2012) yang menyatakan bahwa ROA tidak berpengaruh terhadap return saham.

Proksi rasio profitabilas lainnya yaitu NPM juga menunjukkan hasil penilitian yang beragam. Menurut Pribawanti (2007) dan Hidayat (2009) NPM memiliki pengaruh yang signifikan terhadap return saham pada 
perusahaan. Sedangkan berdasarkan hasil penelitian yang dilakukan oleh Faried (2008), Susilowati (2011) dan Oktanugroho (2012) diperoleh bahwa NPM tidak memiliki pengaruh signifikan terhadap return saham.

Beragamnya hasil penelitian mengenai return saham juga terlihat dari variabel rasio keuangan yang berbeda, salah satunya yaitu dengan rasio likuiditas. Terdapat perbedaan hasil penelitian terdahulu mengenai rasio likuiditas yang diproksikan dengan current ratio. Menurut Ulupui (2005) dan Prihantini (2009) current ratio memiliki pengaruh positif signifikan terhadap return saham perusahaan. Akan tetapi, hal yang berbeda diungkapkan oleh Hidayat (2009) dan Kusumo (2011) bahwa current ratio tidak memiliki pengaruh terhadap return saham.

Rasio leverage yang diproksikan dengan DER dan DAR juga memperlihatkan hal yang serupa. Menurut Solechan (2009) dan Oktanugroho (2012) DER memiliki pengaruh secara signifikan terhadap return saham. Namun hal ini berbeda dengan hasil penelitian yang dilakukan oleh Ulupui (2005), Kusumo (2011), dan Saputra (2012) yang menyatakan bahwa DER tidak berpengaruh secara signifikan terhadap return saham. Dalam penelitian Pribawanti (2007) dan Widyawati (2012) diperoleh hasil bahwa DAR berpengaruh negatif signifikan terhadap return saham. Namun hal ini berbeda dengan hasil yang dilakukan Oktanugroho (2012) yang menyatakan bahwa DAR tidak memiliki pengaruh signifikan terhadap return saham.

Perbedaan lainnya juga ditunjukkan pada rasio aktivitas yang mengalami inkonsistensi hasil dengan proksi yang digunakan yaitu Total Asset Turnover (TAT). Widodo (2007) dan Kusumo (2011) memeroleh hasil bahwa TAT berpengaruh positif signifikan terhadap return saham. Hal ini berbeda dengan penelitian yang dilakukan oleh Ulupui (2005), Hidayat (2009) dan Oktanugroho (2012) yang memperoleh hasil bahwa TAT tidak memiliki pengaruh terhadap return saham. Dengan adanya perbedaan hasil penelitian terdahulu maka dibutuhkan penelitian lebih lanjut untuk menguji kembali variabel-variabel yang mengalami ketidakonsitensian tersebut.

Penelitian ini merupakan replikasi dari penelitian yang dilakukan oleh Oktanugroho (2012). Peneliti tertarik untuk meneliti kembali karena masih beragamnya hasil mengenai pengaruh kinerja keuangan dengan analisis rasio keuangan dalam memprediksi return saham dan untuk melihat reaksi para pemegang saham dalam menilai kinerja perusahaan untuk menghasilkan return yang diharapkan pada masa turunnya tingkat pertumbuhan industri manufaktur hingga adanya peningkatan industri manufaktur selama tahun 2009-2012.

Perbedaan dalam penelitian ini yaitu, peneliti mencoba untuk menambah variabel independen yaitu rasio Market Value yang diproksikan dengan Market to Book Value untuk melihat pengaruh pergerakan harga pasar saham terhadap return saham yang dihasilkan dan menguji kembali variabel independen yaitu rasio keuangan yang mengalami inkonsistensi serta mengganti tahun pengamatan menjadi tahun 2009-2012.

\section{Rumusan Masalah}

Apakah terdapat pengaruh pengukuran kinerja keuangan secara partial dengan menggunakan ROA, ROE, NPM, Current Ratio, TAT, DER, DAR, MBV terhadap return saham pada perusahaan manufaktur?

\section{RERANGKA TEORI DAN PENGEMBANGAN HIPOTESIS}

\section{Teori Signaling}

Teori signal merupakan teori yang membahas mengenai bagaimana signalsignal tentang keberhasilan atau kegagalan manajemen tersebut disampaikan kepada investor. Signal yang disampaikan oleh manajemen biasanya berupa laporan keuangan yang berfungsi untuk mengetahui apakah menejemen telah melaksanakan sesuai dengan kontraknya atau belum (Widyawati, 2012).

Perusahaan yang mengalami pertumbuhan baik dalam dunia industri serta menghasilkan pendapatan yang tinggi tentu 
akan memberikan signal kepada pasar dengan mempublikasikan laporan keuangannya untuk dapat menarik para investor dalam menginvestasikan dananya kepada perusahaan. Dengan adanya signal positif yang diberikan oleh perusahaan ke pasar, hal itu akan memberikan keyakinan dan kepercayaan bagi investor untuk memeroleh return saham yang baik pula dari perusahaan.

\section{Penelitian Terdahulu dan Penurunan Hipotesis}

\section{Rasio Profitabilitas dan Return Saham}

Rasio profitabilitas dinyatakan dengan proksi ROA, ROE dan NPM sebagai wakil dari rasio profitabilitas untuk mengukur kinerja keuangan perusahaan terhadap return saham.

a) Return on Asset (ROA)

Return on Asset merupakan rasio yang digunakan untuk mengukur kemampuan perusahaan dalam menghasilkan laba dengan berdasar pada perbandingan antara laba bersih dengan total aset yang dimiliki perusahaan (Brigham dan Houston, 2010: 148). Menurut Prihantini (2009) semakin besar ROA yang dihasilkan oleh perusahaan maka akan mengindikasikan bahwa kinerja perusahaaan dalam menghasilkan laba semakin tinggi, sehingga tingginya laba yang diperoleh perusahaan akan berdampak pada peningkatan return yang diperoleh para pemegang saham dari dividen yang akan diterima. Peningkatan dividen ini akan memberikan daya tarik bagi para investor atau calon investor untuk menanamkan dananya kepada perusahaan atau memiliki saham perusahaan tersebut. Dengan adanya peningkatan permintaan saham suatu perusahaan maka hal itu akan meningkatkan harga sahamnya sehingga return yang akan diperoleh investor dari saham tersebut juga akan meningkat.

Hal ini dipertegas dengan
penelitian yang dilakukan oleh
Hardiningsih (2001) dan Ulupui (2005) yang menyatakan bahwa ROA berpengaruh secara positif dan signifikan terhadap return saham. Hal yang sama juga diungkapkan oleh Pribawanti (2007), Prihantini (2009) dan Oktanugroho (2012) bahwa ROA memiliki pengaruh positif signifikan terhadap return saham perusahaan, maka hipotesis satu dapat dirumuskan sebagai berikut:

$H_{1}$ : ROA memiliki pengaruh positif yang signifikan terhadap return saham pada perusahaan manufaktur

\section{b) Return on Equity (ROE)}

Return on Equity merupakan rasio yang digunakan untuk mengukur kemampuan perusahaan dalam menghasilkan laba dengan berdasar pada perbandingan antara laba bersih dengan ekuitas biasa, yang biasanya digunakan untuk mengukur tingkat pengembalian atas investasi pemegang saham biasa (Brigham dan Houston, 2010: 149). Semakin besar rasio ini dihasilkan maka itu memberikan sinyal semakin kuatnya kedudukan dari para pemegang saham, karena ROE merupakan rasio profitabilitas dari para pemegang saham. Menurut Fidhayatin (2012) tingginya nilai ROE yang dihasilkan menunjukkan bahwa semakin efektif dan efisiensinya kinerja perusahaan dalam pengelolaan modal yang telah ditanamkan para pemegang saham guna memaksimalkan laba yang tinggi. Tingginya laba yang dihasilkan perusahaan maka akan berdampak pada meningkatnya return yang akan diterima para pemegang saham.

Hal ini dipertegas berdasarkan pada penelitian yang telah dilakukan oleh Widodo (2007) bahwa ROE memiliki pengaruh positif signifikan terhadap return saham perusahaan. Hasil yang sama juga dinyatakan oleh Fidhayatin (2012) dan Widyawati 
(2012) bahwa ROE memiliki pengaruh signifikan terhadap return saham pada perusahaan, maka hipotesis dua dapat dirumuskan sebagai berikut:

$\mathrm{H}_{2}$ : ROE memiliki pengaruh positif yang signifikan terhadap return saham pada perusahaan manufaktur.

\section{c) Profit Margin on Sales (NPM)}

Profit Margin on Sales adalah rasio yang digunakan untuk mengukur kemampuan perusahaan dalam menghasilkan laba yang berdasar pada perbandingan antara laba bersih dengan penjualannya (Brigham dan Houston, 2010: 146). Menurut Pribawanti (2007) jika nilai NPM yang dihasilkan tinggi maka itu menunjukkan semakin efisien biaya yang dikeluarkan guna memaksimalkan tingkat keuntungan yang diperoleh. Semakin tinggi keuntungan yang diperoleh perusahaan, memberikan sinyal kepada para investor (pemegang saham) bahwa return yang akan diterima juga akan meningkat yaitu berupa dividen yang diterimanya. Keuntungan yang tinggi juga akan memberikan daya tarik bagi para calon investor untuk memiliki saham perusahaan sehingga hal itu akan membuat harga saham meningkat yang akhirnya akan berpengaruh terhadap meningkatnya return yang akan diterima oleh para investor (pemegang saham).

Hal ini dipertegas berdasarkan hasil penelitian terdahulu yang telah dilakukan oleh Pribawanti (2007) bahwa NPM memiliki pengaruh yang signifikan terhadap total return saham. Hal ini didukung oleh Hidayat (2009) yang menyatakan bahwa NPM memiliki pengaruh positif signifikan terhadap return saham perusahaan, maka hipotesis tiga dapat dirumuskan sebagai berikut:

$H_{3}$ : NPM memiliki pengaruh positif yang signifikan terhadap return saham pada perusahaan manufaktur.

\section{Rasio Lukuiditas dan Return Saham}

Rasio Likuiditas adalah rasio yang digunkaan untuk mengetahui kemampuan perusahaan dalam memenuhi kewajibannya. Proksi yang mewakili rasio likuiditas yaitu Current ratio. Current Ratio merupakan rasio perbandingan antara asset lancar dengan hutang lancar (Cahyati dalam Prihantini 2009). Semakin tinggi rasio yang dihasilkan, hal itu akan memberikan sinyal bahwa perusahaan memiliki kinerja yang baik dimana ditunjukkan dengan semakin baiknya kemampuan perusahaan dalam memenuhi kebutuhan kewajibanya, maka hal tersebut akan memberikan keyakinan kepada para investor untuk memiliki saham-saham perusahaan (Prihantini, 2009). Dengan adanya peningkatan permintaan saham dari para investor atau calon investor maka akan menaikkan harga saham perusahaan tersebut, sehingga return saham juga akan mengalami peningkatan.

Hal ini dipertegas dari penelitian yang telah dilakukan oleh Ulupui (2005) bahwa Current Ratio memiliki pengaruh positif yang signifikan terhadap return saham. Hal ini didukung oleh Prihantini (2009) yang menyatakan hasil yang sama bahwa Current Ratio memiliki pengaruh yang positif terhadap return saham perusahaan, sehingga hipotesis empat dapat dirumuskan sebagai berikut:

$\mathrm{H}_{4}$ : Current Ratio memiliki pengaruh positif signifikan terhadap return saham pada perusahaan manufaktur

\section{Rasio Aktivitas dan Return Saham}

Rasio aktivitas merupakan rasio yang digunkan untuk mengukur seberapa efektif perusahaan dalam mengelola aset yang dimiliki (Ang dalam Astuti, 2006). Proksi yang mewakili penelitian ini yaitu TAT. Menurut Sartono melalui Widodo (2007) ketika perusahaan menghasilkan rasio TAT yang tinggi, hal ini menunjukkan semakin efektif perusahaan 
dalam mengelola aset yang dimiliki dalam kaitannya menghasilkan penjualan yang tinggi dan diharapkan laba yang diperoleh juga akan mengalami peningkatan. Peningkatan laba yang diperoleh menunjukkan bahwa kinerja perusahaan semakin baik. Kinerja perusahaan yang semakin baik akan memberikan dampak pada meningkatnya harga saham sehingga dengan harga saham yang tinggi maka return saham yang dihasilkan juga semakin besar.

Hal ini dipertegas dari hasil penelitian terdahulu yang dilakukan oleh Widodo (2007) bahwa TAT memiliki pengaruh positif signifikan terhadap return saham. Kusumo (2011) dalam penelitiannya juga memperoleh hasil bahwa TAT memiliki pengaruh yang signifikan terhadap return saham, sehingga hipotesis lima dapat dirumuskan sebagai berikut:

$H_{5}$ : TAT memiliki pengaruh positif signifikan terhadap return saham pada perusahaan manufaktur.

\section{Rasio Leverage dan Return Saham}

Rasio Leverage adalah rasio yang menunjukkan kemampuan perusahaan dalam memenuhi kewajiban keuangannya apabila perusahaan tersebut dilikuidasi, baik kewajiban keuangan jangka pendek maupun jangka panjang (kasmir dalam Oktanugroho, 2012). Proksi yang digunakan dalam rasio leverage ini yaitu DER dan DAR.

a) Debt to Equity (DER)

Debt to Equity adalah rasio yang digunakan untuk menunjukkan kemampuan perusahaan dalam memenuhi kewajibannya yang ditunjukkan dengan beberapa bagian dari ekuitas atau modal sendiri yang digunakan perusahaan untuk membayar hutang (Prihantini, 2009). Menurut Oktanugroho (2012) semakin tinggi DER yang dihasilkan oleh perusahaan menunjukkan bahwa semakin besar komposisi hutang yang dimiliki perusahaan dibandingkan dengan total modal atau ekuitasnya, sehingga hal itu menunjukkan semakin besarnya beban perusahaan terhadap pihak luar (kreditur). Ang dalam Pribawanti (2007) menambahkan bahwa peningkatan beban terhadap pihak luar (kreditur) mencerminkan bahwa sumber modal perusahaan sangat tergantung kepada pihak luar sehingga hal itu dapat mengurangi minat investor untuk menanamkan dananya ke perusahaan. Penurunan minat investor dalam menanamkan dananya berdampak pada penurunan harga saham perusahaan sehingga akan menurunkan return saham yang diperoleh para pemegang saham.

Hal ini didukung dengan penelitian yang telah dilakukan oleh Pribawanti (2007) yang menyatakan bahwa DER memiliki pengaruh signifikan terhadap return saham. Hal yang sama juga diungkapkan oleh Solechan (2009), Prihantini (2009) dan Oktanugroho (2012) bahwa DER memiliki pengaruh negatif signifikan terhadap return saham, maka hipotesis enam dapat dirumuskan sebagai berikut:

$H_{6}$ : DER memiliki pengaruh negatif signifikan terhadap return saham pada perusahaan manufaktur.

b) Debt to total Asset (DAR)

Debt to total Asset adalah rasio yang digunakan untuk mengukur kemampuan perusahaan dalam memenuhi kewajibannya dengan berdasar pada total aset perusahaan. Menurut Faisal Matriadi dalam Widyawati (2012) apabila DAR yang dihasilkan oleh suatu perusahaan semakin tinggi, maka hal itu memberikan sinyal bahwa resiko yang dihadapi perusahaan akan semakin besar karena menunjukkan semakin besarnya hutang perusahaan terhadap kreditur. Hal tersebut akan membawa dampak pada menurunnya kinerja perusahaan akibat berkurangnya laba 
bersih yang diperoleh perusahaan dimana sebagian penghasilan perusahaan harus dibayarkan kepada kreditur dalam bentuk bunga pinjaman. Apabila laba yang dihasilkan oleh perusahaan tidak cukup untuk membayar bunga pinjaman maka perusahaan akan berada pada posisi default yang mengarah pada kebangkrutan. Dengan kondisi seperti itu, harga saham akan semakin menurun sehingga tingkat return yang diperoleh para pemegang saham akan semakin kecil.

Berdasarkan pada hasil penelitian terdahulu yang telah dilakukan oleh Pribawanti (2007) bahwa DAR memiliki pengaruh negatif yang signifikan terhadap return saham pada perusahaan. Hal ini dipertegas oleh Widyawati (2012) yang memperoleh hasil yang sama, maka dapat ditarik hipotesis tujuh yaitu:

$H_{7}$ : DAR memiliki pengaruh negatif signifikan terhadap return saham pada perusahaan manufaktur.

\section{Rasio Market Value dan Return Saham}

Rasio Nilai pasar merupakan rasio yang digunakan untuk mengukur harga pasar saham relative terhadap laba, arus kas, dan nilai bukunya (Bringham dan Houston, 2010: 151). Salah satu proksi yang digunakan dalam rasio ini yaitu dengan menggunakan MBV. Market to Book Value adalah rasio yang digunakan untuk mengukur harga saham terhadap nilai bukunya. Semakin tinggi rasio ini dihasilkan maka akan semakin tinggi pula perusahaan dinilai oleh investor. Ketika perusahaan dinilai lebih tinggi oleh para investor, hal ini mencerminkan tingkat kemakmuran dari para pemegang saham, dimana harga saham di pasar mengalami peningkatan. Dengan demikian semakin tinggi nilai MBV yang dihasilkan akan berpengaruh positif terhadap kenaikan harga sahamnya sehingga return sahamnya pun akan ikut meningkat.
Berdasarkan penelitian yang telah dilakukan oleh Astuti (2006) diperoleh hasil bahwa MBV berpengaruh positif yang signifikan terhadap return saham pada perusahaan manufaktur yang terdaftar di BEI. Hal ini didukung oleh Margaretha dan Damayanti (2008) dan Arista (2012) yang menyatakan hal yang sama. Dari penjelasan tersebut maka hipotesis delapan dapat dirumuskan sebagai berikut:

$H_{8}$ : MBV memiliki pengaruh positif signifikan terhadap return saham pada perusahaan manufaktur.

\section{METODE PENELITIAN}

Dalam penelitian ini objek penelitian yang digunakan yaitu Perusahaan Manufaktur yang terdaftar dalam Bursa Efek Indonesia pada periode tahun 2009 sampai dengan 2012. Jenis data yang digunakan dalam penelitian ini adalah data sekunder dengan bersumber dari informasi laporan keuangan 2009 sampai dengan 2012 dan data pasar saham akhir tahun (2008-2012) yang berasal dari Bursa Efek Indonesia, melalui Indonesion Stock Exchange (IDX), Yahoo Finance dan situs resmi perusahaan.

Pada penelitian ini, penentuan Perusahaan Manufaktur yang dijadikan sampel dilakukan dengan teknik purposive sampling, yaitu suatu metode dengan berdasarkan pada pertimbanganpertimbangan dan kriteria-kriteria tertentu. Kriteria yang dibutuhkan dalam sampel penelitian yaitu:

1. Perusahaan Manufaktur yang terdaftar di Bursa Efek Indonesia (BEI) pada tahun 2009 sampai dengan 2012

2. Perusahaan Manufaktur yang memiliki laporan keuangan (Annual Report) yang telah dipublikasikan setiap tahun berturut-turut

3. Perusahaan Manufaktur yang memiliki informasi harga saham akhir tahun selama periode pengamatan, serta memiliki data lengkap sesuai dengan pengamatan.

Teknik pengumpulan data yang digunakan adalah dokumentasi. Metode ini 
digunakan untuk memperoleh data laporan keuangan perusahaan manufaktur yang terdaftar di BEI tahun 2009-2012 seperti neraca, laporan laba rugi, laporan arus kas dan data informasi harga saham akhir tahun yang diperlukan untuk proses penelitian. Variabel yang digunakan dalam penelitian ini adalah:

1. Variabel Dependen

Variabel dependen dalam penelitian ini adalah return saham. Return saham adalah tingkat keuntungan yang diperoleh para investor atas hasil investasi yang dilakukannya (Prihantini, 2009). Return saham dihitung dengan selisih antara harga saham dengan harga saham pada periode sebelumnya dan ditambah dengan deviden yang dibayarkan setiap periodik, kemudian dibagi dengan harga saham. Persamaan return saham dapat dirumuskan secara sistematis yaitu (Jogiyanto, 2000):

$$
R i_{t}=\frac{P_{t}-P_{t-1}+D_{t}}{P_{t-1}}
$$

$R i_{t}=$ return saham pada periode $\mathrm{t}$

$P_{t}=$ harga saham pada periode $\mathrm{t}$

$P_{t-1}=$ harga saham pada periode $\mathrm{t}-1$

$D_{t}=$ deviden yang dibayarkan pada periode $\mathrm{t}$

2. Variabel Independen

a. Rasio Profitabilitas

Rasio profitabilitas adalah rasio yang digunakan untuk mengukur kemampuan perusahaan dalam menghasilkan laba. Proksi yang digunakan dalam rasio profitabilitas yaitu:

1) Return on Asset (ROA)

Return on Asset merupakan rasio yang digunakan untuk mengukur kemampuan perusahaan dalam menghasilkan keuntungan dengan dihitung berdasarkan pada perbandingan laba bersih setelah pajak terhadap total asset, yang dirumuskan sebagai berikut (Brigham dan Houston, 2011):

Return On Asset $=\frac{\text { Laba Bersih }}{\text { Total Asset }} \times 100 \%$
2) Return on Equity (ROE)

Return on Equity merupakan rasio profitabilitas yang dihitung berdasarkan pada perbandingan antara laba bersih setelah pajak dengan ekuitasnya, yang dapat dirumuskan sebagai berikut (Brigham dan Houston, 2011):

$$
\text { Return On Equity }=\frac{\text { Laba Bersih }}{\text { Equity }} \times 100 \%
$$

3) Profit Margin on Sales (NPM) Profit Margin on Sales adalah rasio yang digunakan untuk mengukur kemampuan perusahaan dalam menghasilkan keuntunga yang dihitung berdasarkan pada perbandingan antara laba bersih setelah pajak dengan penjualan, di mana dapat dirumuskan sebagai berikut (Bringham \& Houston, 2010):

Profit Margin on Sales $=\frac{\text { Laba Bersih }}{\text { Penjualan }} \times 100 \%$

b. Rasio Likuiditas

Raiso Likuiditas merupakan
rasio yang digunakan untuk mengukur kemampuan perusahaan dalam memenuhi kewajibannya. Rasio likuiditas dalam penelitian ini diwakili dengan Current Ratio (CR). Current Ratio adalah alat yang digunakan untuk mengukur kemampuan likuiditas yaitu kemampuan dalam membayar hutang yang segera harus dipenuhi dengan aktiva lancar (Prihantini, 2009). Secara sistematis Current ratio dirumuskan sebagai berikut (Bringham \& Houston, (20ront assets Current Ratio $=\frac{\text { Current Liabilities }}{\text { Ciarion }}$

c. Rasio Aktivitas

Rasio aktivitas adalah rasio yang menggambarkan hubungan antara tingkat operasi perusahaan dengan asset perusahaan yang dibutuhkan secara efisien dalam rangka untuk memenuhi operasi kegiatan 
perusahaan. Proksi rasio aktivitas yang digunakan dalam penelitian ini yaitu TAT yang dihitung dengan membagi penjualan dengan total aset perusahaan yang mana dirumuskan sebagai berikut (Bringham \& Houston, 2010):

Total Asset Turnover $($ TAT $)=\frac{\text { Prnjualan }}{\text { Total Asset }}$

d. Rasio Leverage

Rasio Leverage merupakan rasio yang digunakan perusahaan untuk mengukur kemampuan perusahaan dalam memenuhi seluruh kewajiban finansialnya apabila perusahaan dilikuidasi (Solechan, 2009). Proksi Rasio Leverage yang digunakan antara lain:

1) Debt to Equity Ratio (DER)

Debt to Equity Ratio merupakan rasio untuk mengukur tingkat kecukupan ekuitas dalam menjamin keseluruhan hutang yang dimiliki oleh perusahaan, DER dapat dihitung berdasarkan pada perbandingan antara total hutang dengan ekuitasnya. Rasio DER dapat dirumuskan sebagai berikut (Kasmir melalui Oktanugroho, 2012):

Debt to Total Equity $=\frac{\text { Total Debt }}{\text { Total Equity }} \times 100 \%$

2) Debt to Total Asset (DAR)

Debt to Total Asset merupakan rasio yang digunakan untuk mengukur kemampuan perusahaan dalam melunasi keseluruhan hutang yang dimiliki dengan total aset perusahaan. Rasio DAR dapat dirumuskan sebagai berikut (Kasmir melalui Oktanugroho, 2012):

Debt to Total Asset $=\frac{\text { Total Debt }}{\text { Total Asset }} \times 100 \%$

e. Rasio Nilai Pasar (Market Value) Market value merupakan sekumpulan rasio yang menghubungkan harga saham perusahaan dengan laba, arus kas, dan nilai buku per sahamnya. Proksi yang digunakan dalam rasio ini yaitu MBV. Market to Book Value adalah rasio perbandingan antara harga saham dengan nilai bukunya. Rasio MBV dapat dirumuskan sebagai berikut (Bringham \& Houston, 2010):

Market to Book Value $=\frac{\text { Harga pasar saham }}{\text { Nilai buku per saham }}$

\section{Uji Kualitas Data}

1. Statistik Deskriptif

Statistik Deskriptif merupakan gambaran atau deskripsi suatu data yang dilihat dari nilai rata-rata (mean), standar deviasi, varian, maksimum, minimum, sum, range, kurtosis dan skewness atau kemencengan distribusi (Ghozali, 2011).

2. Uji Asumsi Klasik

Dalam penelitian ini data yang digunakan merupakan data sekunder sehingga untuk menentukan ketepatan model yang digunakan perlu untuk dilakukan pengujian beberapa asumsi klasik yang mendasari model regresi. Uji asumsi klasik tersebut meliputi:

a. Uji Normalitas

Suatu model regresi yang baik yaitu model yang memiliki distribusi normal. Uji normalitas data dilakukan dengan One-KolmogrovSmirnov Test. Data dapat dikatakan berdistribusi normal ketika nilai kolmogrov-Smirnov > 0,05 (Ghozali, 2006).

b. Uji Multikolinieritas

Suatu model regresi dikatakan baik apabila antar variabel independen tidak terjadi multikolinieritas. Uji multikolinieritas ini dilakukan dengan uji Tolerance dan Variance Inflation Factor (VIF). Data dapat dikatakan tidak mengandung multikolinieritas ketika nilai VIF < 10 atau nilai tolerance $>0,10$ (Ghozali, 2011). c. Uji Autokorelasi 
Suatu model regresi yang baik yaitu model regresi yang bebas dari autokorelasi. Dalam menguji autokorelasi dalam penelitian ini dilakukan uji Durbin Wattson dimana hasil yang menunjukkan bebas dari autokorelasi apabila DU $\leq$ DWhitung $\leq$ 4-DU. (Ghozali, 2011)

\section{d. Uji Heteroskedastisitas}

Model regresi yang baik adalah model yang tidak terjadi heteroskedatisitas. Pengujuan heteroskedastisitas dilakukan dengan uji glejser. Uji glejser merupakan uji yang mengusulkan untuk meregres nilai absolute $\begin{array}{llr}\text { residual } & \text { terhadap } & \text { variabel } \\ \text { independen } & \text { (Gujarati } & \text { dalam }\end{array}$ Ghozali, 2011) dengan permasaan regresi:

$$
|\mathrm{Ut}|=\alpha+\beta X_{t}+v t
$$

\section{Uji Hipotesis dan Analisis Data}

Dalam menguji hipotesis mengenai kekuatan variabel independen terhadap return saham dalam penelitian ini digunakan analisis regresi berganda dengan dirumuskan model dasar sebagai berikut:

$$
R i_{t}=\alpha+B_{1} R O A+B_{2} R O E+B_{3} N P M+B_{4} C R+B_{5} T A T+B_{6} D E R+B_{7} D A R+B_{8} M B V+e
$$

$\begin{array}{ll}R i_{t} & =\text { Return Saham } \\ \alpha & =\text { Konstanta } \\ \text { ROA } & =\text { Return On Asset } \\ \text { ROE } & =\text { Return On Equity } \\ \text { NPM } & =\text { Profit Margin on Sales } \\ B_{1}-B_{5} & =\text { Koefisien Regresi } \\ \text { DER } & =\text { Debt To Equity Ratio }\end{array}$

\section{a. Uji Nilai F (Simultan)}

Pengujian terhadap hipotesis dalam penelitian ini dilakukan dengan menguji variabel independent terhadap variabel dependen secara bersama-sama. Uji F digunakan untuk menguji keberartian pengaruh semua variabel independen secara bersama-sama dalam memengaruhi variabel dependen. Apabila nilai Sig $\mathrm{F}<\alpha$ $(5 \%)$, maka terdapat pengaruh secara bersama-sama variabel independen terhadap variabel dependen. $b$. Uji NIlai $t$ (Parsial)

Pengujian terhadap hipotesis dalam penelitian ini dilakukan dengan menguji variabel independen terhadap variabel dependen secara satu persatu. Uji nilai t ini digunakan untuk menguji secara individu pengaruh variabel-variabel independen
$\mathrm{CR}=$ Current Ratio

TAT = Total Asset Turnover

DAR $=$ Debt to Total Asset Ratio

MBV = Market to Book Value

$\mathrm{e} \quad=$ Unit Eror

terhadap variabel dependennya. Kriteria penerimaan hipotesis dalam uji nilai t yaitu Apabila nilai sig $<\alpha$ dengan derajat kepercayaan $5 \%$ maka $H_{a}$ dapat diterima. Hal itu berarti bahwa variabel independen dapat menerangkan variabel dependen dan terdapat pengaruh signifikan diantara kedua variabel yang di uji, serta koefisien regresi searah dengan hipotesisnya.

c. Uji Koefisien Determinasi (Adj. $R^{2}$ )

Uji koefisien determinasi digunakan untuk menjelaskan tingginya derajat hubungan antara variabel independen terhadap variabel dependen. Nilai koefisien determinasi yang mendekati 1 menunjukkan bahwa semakin besar pengaruh variabel independen terhadap variabel dependen (Ghozali, 2011). 


\section{HASIL PENELITIAN DAN \\ PEMBAHASAN}

\section{Gambaran Umum Obyek Penelitian}

Di dalam penelitian ini, sampel yang menjadi obyek penelitian yaitu perusahaan manufaktur yang terdaftar di Bursa Efek Indonesia (BEI) selama tahun 2009 sampai dengan 2012. Pengambilan sampel dalam penelitian ini dilakukan melalui purposive sampling sehingga diperoleh sampel sebanyak 95 perusahaan yang lolos sesuai dengan kriteria yang telah ditentukan. Uji Asumsi Klasik a. Uji Normalitas

TABEL 1

HASIL UJI NORMALITAS

\begin{tabular}{llr}
\hline & & $\begin{array}{c}\text { Unstandardized } \\
\text { Residual }\end{array}$ \\
\hline $\mathrm{N}$ & & 348 \\
Normal Parameters(a,b) & Mean &, 0000000 \\
& Std. Deviation &, 50331132
\end{tabular}

Most Extreme Differences

$\begin{array}{ll}\text { Absolute } & , 048 \\ \text { Positive } & , 048 \\ & -, 035 \\ \text { Negative } & \end{array}$

,900

Kolmogorov-Smirnov Z

Asymp. Sig. (2-tailed)

Sumber: Hasil Pengolahan Data Statistik Dengan SPSS 15.0

Berdasarkan hasil pengujian normalitas dengan menggunakan onesample kolmogorov-smirnov test diperoleh nilai signifikansi sebesar $0,393>0,05$ sehingga dapat disimpulkan bahwa data telah berdistribusi normal. b. Uji Multikolinieritas

Model regresi akan bebas dari masalah multikolinieritas jika nilai VIF < 10 dan nilai tolerance $>0,10$.

TABEL 2

HASIL UJI MULTIKOLINIERITAS

\begin{tabular}{|c|c|c|c|c|}
\hline \multirow[t]{2}{*}{ Model } & & \multicolumn{2}{|c|}{ Collinearity Statistics } & \multirow{2}{*}{ Keterangan } \\
\hline & & Tolerance & VIF & \\
\hline \multicolumn{5}{|c|}{1 (Constant) } \\
\hline & $\mathrm{ROA}$ & ,371 & 2,696 & Non Multikolinieritas \\
\hline & $\mathrm{ROE}$ & 687 & 1,456 & Non Multikolinieritas \\
\hline & NPM &, 565 & 1,771 & Non Multikolinieritas \\
\hline & CR & 935 & 1,070 & Non Multikolinieritas \\
\hline & TAT & 822 & 1,217 & Non Multikolinieritas \\
\hline \multirow[b]{2}{*}{ DAR } & DER & , 802 & 1,246 & Non Multikolinieritas \\
\hline & & ,712 & $\begin{array}{l}1,240 \\
1,405\end{array}$ & Non Multikolinieritas \\
\hline
\end{tabular}




\begin{tabular}{crrr}
\hline MBV &, 639 & 1,564 & Non Multikolinieritas \\
\hline Sumber: Hasil Pengolahan Data Statistik & Dengan SPSS 15.0
\end{tabular}

Berdasarkan hasil pengujian yang dilakukan pada tabel 4.4 tampak bahwa tidak ada nilai VIF dari setiap variabel yang lebih besar dari 10 dan tidak ada nilai tolerance yang kurang dari 0,10 . Dengan demikian dapat disimpulkan bahwa semua variabel tidak memiliki masalah multikolinieritas.

c. Uji Autokorelasi

Model regresi dapat dikatakan bebas dari masalah autokorelasi apabila nilai Durbin Watson (DW) yang dihasilkan yaitu $\mathrm{DU}<\mathrm{DW}<4-\mathrm{DU}$.

TABEL 3

HASIL UJI AUTOKORELASI

\begin{tabular}{lrrrrr}
\hline Model & R & R Square & \multicolumn{1}{c}{$\begin{array}{c}\text { Adjusted R } \\
\text { Square }\end{array}$} & $\begin{array}{l}\text { Std. Error of } \\
\text { the Estimate }\end{array}$ & \multicolumn{1}{c}{$\begin{array}{l}\text { Durbin- } \\
\text { Watson }\end{array}$} \\
\hline 1 & & & & & \\
&, $394(\mathrm{a})$ &, 156 &, 136 &, 50922 & 1,902
\end{tabular}

\section{Berdasarkan pengujian}

Autokorelasi, dihasilkan bahwa nilai DW sebesar 1,902 dan nilai ini akan dibandingkan dengan nilai tabel DU. Variabel independen yang digunakan dalam penelitian $(\mathrm{k})=8$ dan jumlah data sebanyak 348 (n) sehingga diperoleh nilai tabel DU sebesar 1,852. Dari hasil tersebut, maka dapat dibandingkan bahwa
DU $1,852 \leq 1,902 \leq 4-1,852$. Berdasarkan hasil perbandingan nilai Durbin Watson tersebut dapat disimpulkan bahwa data penelitian yang digunakan bebas dari masalah autokorelasi dalam model regresi.

d. Uji Heteroskedastisitas

TABEL 4

HASIL UJI HETEROSKEDASTISITAS

\begin{tabular}{|c|c|c|c|c|c|c|}
\hline & Model & $\begin{array}{r}\text { Unstandar } \\
\text { Coefficie }\end{array}$ & & $\begin{array}{l}\text { Standardized } \\
\text { Coefficients }\end{array}$ & & \\
\hline & & B & $\begin{array}{l}\text { Std. } \\
\text { Error }\end{array}$ & Beta & $\mathrm{t}$ & Sig. \\
\hline 1 & (Constant) & ,377 &, 037 & & 10,280 & ,000 \\
\hline & ROA & ,002 &, 002 & ,079 & ,916 & ,360 \\
\hline & ROE & & & & & \\
\hline & $\begin{array}{l}\text { NPM } \\
\text { CR }\end{array}$ & ,001 & ,00 0 & ,114 & 1,800 & 073, \\
\hline & TAT & & & & & \\
\hline & DER & ,002 & ,00 1 &, 127 & 1,822 & ,069 \\
\hline & DAR & & & & & \\
\hline & $\mathrm{MBV}$ &,- 001 & ,003 &,- 013 &,- 237 & ,813 \\
\hline & &,- 018 & ,012 &,- 090 & $-1,559$ & , 120 \\
\hline & & $-3,43 \mathrm{E}-005$ & ,000 &,- 035 &,- 603 &, 547 \\
\hline & & ,000 & ,00 0 & ,050 & ,798 & ,426 \\
\hline & &,- 002 & 003, &,- 042 &,- 632 & ,528 \\
\hline
\end{tabular}


Berdasarkan hasil pengujian heteroskedastisitas dengan Uji Glejser, tampak bahwa nilai signifikansi variabelvariabel independen yang dihasilkan dalam model regresi berada lebih besar daripada 0,05. Dari hasil tersebut maka dapat disimpulkan bahwa model regresi dapat dikatakan bebas dari masalah heteroskedastisitas.

\section{Hasil Uji Hipotesis}

Berdasarkan pada pengolahan data dengan menggunakan software SPSS 15.0 diperoleh hasil nilai koefisien regresi yaitu nilai F (Simultan), nilai $t$ (Partial) dan nilai koefisien determinasi seperti tampak pada tabel 4.6, tabel 4.7, dan tabel 4 .

\section{Uji Nilai F (Simultan)}

TABEL 5

HASIL UJI NILAI F

\begin{tabular}{llrrrrr}
\hline & \multicolumn{5}{c}{ Sean } \\
Model & & Squares & df & Square & \multicolumn{1}{c}{ F } & \multicolumn{1}{c}{ Sig. } \\
\hline 1 & Regression & 16,191 & 8339 & 2,024 & 7,805 &, $000(\mathrm{a})$ \\
& Residual & 87,903 & 347 &, 259 & & \\
& Total & 104,094 & & & & \\
& & & & & & \\
\end{tabular}

Sumber: Hasil Pengolahan Data Statistik Dengan SPSS 15.0

Uji nilai $\mathrm{F}$ merupakan pengujian yang dilakukan untuk mengetahui pengaruh variabel independen terhadap variabel dependen secara bersama-sama. Berdasarkan hasil perhitungan pada tabel 4.7 tampak bahwa nilai $F$ sebesar 7,805 dengan signifikansi 0,000.

Hal itu menunjukkan bahwa nilai sig $\mathrm{F}$ $(0,000)<a(0,05)$, maka terdapat pengaruh secara bersama-sama variabel independen terhadap variabel dependennya. Berdasarkan hasil uji nilai $\mathrm{F}$ dapat disimpulkan bahwa penggabungan variabel ROA, ROE, NPM, Current Ratio, TAT, DER, DAR, MBV relevan digunakan untuk memprediksi return saham pada perusahaan manufaktur di masa yang akan datang.

\section{Uji Nilai t (Partial)}

Dari hasil perhitungan tabel 4.7 dapat diketahui nilai konstanta $(\alpha)$ dari model regresi adalah 0,178 dan koefisien regresi $(\beta)$ untuk variabel $\mathrm{ROA}\left(X_{1}\right)$ dan $\operatorname{ROE}\left(X_{2}\right)$ adalah $\beta_{1}=0,020 ; \beta_{2}=0,002$. Berdasarkan nilai konstanta dan koefisien regresi tersebut, maka hubungan variabel independen dengan variabel dependen dalam model regresi dapat dirumuskan sebagai berikut:

$$
\text { Rit }=0,178+0,020 R O A+0,002 R O E+e
$$

Hasil model regresi tersebut menunjukkan arah pengaruh dari variabel independen yaitu ROA dan ROE terhadap variabel dependen yaitu Return saham dalam perusahaan manufaktur yang terdaftar di Bursa Efek Indonesia. Variabel ROA dan ROE memiliki pengaruh yang positif terhadap return saham.

TABEL 6

HASIL KOEFISIEN REGRESI DAN UJI NILAI t

Unstandardized
Coefficients

B Std. Error Sig. Keterangan 


\begin{tabular}{|c|c|c|c|c|c|}
\hline 1 & (Constant) & ,178 & ,062 & ,004 & \\
\hline & ROA & ,020 & ,004 & ,000 & $\mathrm{H}_{1}$ DITERIMA \\
\hline & ROE & ,002 & ,001 & .045 & $\mathrm{H}_{2}$ DITERIMA \\
\hline & NPM &,- 001 &, 002 & ,743 & $\mathrm{H}_{3}$ DITOLAK \\
\hline & CR & & & & $\mathrm{H}_{4}$ DITOLAK \\
\hline & TAT & 005, & 006, & 376, & $\mathrm{H}_{5}$ DITOLAK \\
\hline & DER &,- 009 & ,020 & ,665 & $\mathrm{H}_{6}$ DITOLAK \\
\hline & DAR & $8,34 \mathrm{E}-005$ & ,000 & ,385 & $\mathrm{H}_{7}$ DITOLAK \\
\hline & MBV & 000 & 001 & ,788 & $\mathrm{H}_{8}$ DITOLAK \\
\hline & &,- 008 & ,006 & , 164 & \\
\hline
\end{tabular}

Sumber: Hasil Pengolahan Data Statistik Dengan SPSS 15.0

\section{Koefisien Determinasi}

TABEL 7

HASIL KOEFISIEN DETERMINASI

\begin{tabular}{llccrr}
\hline & \multicolumn{3}{c}{$\begin{array}{c}\text { Adjusted R } \\
\text { Square }\end{array}$} & $\begin{array}{c}\text { Std. Error of } \\
\text { the Estimate }\end{array}$ & Durbin-Watson \\
\hline 1 & $\mathrm{R}$ & R Square & , 136 &, 50922 & 1,902 \\
\hline \multicolumn{7}{l}{ Sumber: Hasil Pengolahan Data Statistik } & Dengan SPSS 15.0
\end{tabular}

Berdasarkan hasil perhitungan dalam tabel 4.8 nilai koefisien determinasi (Adjusted $R^{2}$ ) sebesar 0,136 yang berarti bahwa variabel dependen dapat dijelaskan oleh variabel independen sebesar 13,6\%. Sedangkan sisanya sebesar $86,4 \%$ dijelaskan oleh variabel lain yang tidak masuk dalam model regresi penelitian.

\section{Pembahasan}

\section{Return on Asset (ROA)}

Return on Asset memiliki pengaruh positif yang signifikan terhadap return saham pada perusahaan manufaktur, karena nilai sig t yang dihasilkan sebesar

diterima. Hasil analisis ini menunjukkan bahwa perubahan nilai ROA akan memberikan kontribusi yang positif dan signifikan terhadap perubahan return saham pada perusahaan manufaktur, yaitu setiap kenaikan atau penurunan ROA yang dihasilkan akan berdampak kepada kenaikan dan penurunan return saham pada perusahaan manufaktur.

Hasil analisis ini mengindikasikan bahwa investor juga menggunakan rasio profitabilitas yaitu ROA untuk mengukur kinerja perusahaan dalam menghasilkan laba yang akan berdampak pada return saham yang akan diperoleh. Hal ini sesuai dengan penjelasan Prihantini (2009) bahwa semakin besar keuntungan yang dihasilkan perusahaan maka return saham yang akan diperoleh investor juga akan semakin meningkat yaitu dari peningkatan dividen yang diterima. Dengan adanya peningkatan dividen yang diterima oleh para pemegang saham, hal ini merupakan daya tarik bagi investor ataupun calon investor untuk memiliki saham perusahaan sehingga saham perusahaam menjadi aktif diperdagangkan. Permintaan saham perusahaan yang semakin tinggi tersebut akan membawa dampak pada kenaikan harga saham perusahaan sehingga return yang akan diperoleh investor dari saham tersebut akan mengalami peningkatan. Hasil penelitian ini sesuai dengan penelitian yang dilakukan oleh Uluipi (2005), Pribawanti (2007), Prihantini (2009) dan Oktanugroho (2012) yang menyatakan bahwa ROA memiliki pengaruh positif yang signifikan terhadap return saham. 


\section{Return on Equity (ROE)}

Return on Equity memiliki pengaruh positif yang signifikan terhadap return saham pada perusahaan manufaktur. Rasio Profitabilitas dengan proksi ROE dapat digunakan untuk memprediksi return saham yang diharapkan oleh investor karena hasil penelitian menyatakan bahwa nilai signifikansi yang

sehingga hipotesis dua diterima. Hasil analisis ini mengindikasikan bahwa setiap kenaikan atau penurunan ROE yang dihasilkan akan berdampak kepada kenaikan dan penurunan return saham pada perusahaan manufaktur. Semakin besar nilai ROE yang dihasilkan maka itu menunjukkan bahwa semakin kuatnya kedudukan dari para pemegang saham, karena perusahaan mampu mengelola modal yang telah ditanamkan secara efektif untuk menghasilkan laba yang maksimal.

Hal itu juga menunjukkan bahwa kinerja perusahaan dalam pengembalian modal yang telah ditanamkan para pemegang saham semakin baik sehingga return yang akan diterima para pemegang saham pun menjadi meningkat. Hasil penelitian ini mendukung penelitian yang telah dilakukan oleh Widodo (2007), Fidhayatin (2012) dan Widyawati (2012) yang memeroleh hasil bahwa ROE memiliki pengaruh yang signifikan terhadap return saham. Namun hasil penelitian ini tidak sesuai dengan Oktanugroho (2012) yang memeroleh hasil bahwa ROE tidak memiliki pengaruh yang signifikan terhadap return saham.

\section{Profit Margin on Sales (NPM)}

Profit Margin on Sales tidak memiliki pengaruh yang signifikan terhadap return saham pada perusahaan manufaktur karena nilai signifikansi yang

$$
\text { NFW yaitu } 0,743>\alpha
$$

sehingga hipotesis tiga ditolak. Hasil penelitian ini mengindikasikan bahwa nilai NPM yang dihasilkan oleh perusahaan tidak memberikan daya tarik bagi investor sebagai dasar pertimbangan dalam melakukan investasi kepada perusahaan karena investor lebih mempertimbangkan informasi dari nilai ROA dan ROE yang dihasilkan perusahaan sehingga nilai NPM ini kurang baik untuk digunakan dalam memprediksi return saham.

Selain itu, menurut Faried (2008) adanya penggunaan variabel rasio profitabilitas secara bersamaan sering dapat memberikan masalah kecenderungan multikolinieritas sehingga variabel-variabel tersebut menjadi kurang predictable. Hasil penelitian ini mendukung penelitian yang telah dilakukan oleh Faried (2008), Susilowati (2011) dan Oktanugroho (2012) yang menyatakan bahwa NPM tidak memiliki pengaruh yang signifikan terhadap return saham pada perusahaan.

\section{Current Ratio}

Rasio likuiditas dengan proksi Current Ratio tidak memiliki pengaruh positif yang signifikan terhadap return saham pada perusahaan manufaktur karena nilai signifikansi t yang dihasilkan

ditolak. Hal ini mengindikasikan bahwa informasi dari Current ratio tidak menyebabkan perubahan return saham pada perusahaan manufaktur sehingga informasi yang disajikan dalam current ratio kurang menarik bagi investor sebagai dasar pertimbangan dalam melakukan penilaian kinerja perusahaan. Hal ini dapat disebabkan karena dari sudut rasio likuiditas, rasio ini hanya memberikan informasi yang berhubungan dengan pemenuhan kewajiban jangka pendeknya saja tetapi tidak memberikan sinyal positif bagi keterlanjutan investasi yang ditanamkan oleh investor. Hasil penelitian ini mendukung penelitian yang dilakukan oleh Hidayat (2009) dan Kusumo (2011) yang menyatakan Current Ratio tidak memiliki pengaruh yang signifikan terhadap return saham. 


\section{Total Asset Turnover (TAT)}

Total Asset Turnover tidak memiliki pengaruh yang signifikan terhadap return saham pada perusahaan manufaktur karena nilai signifikansi yang dihasilkan TAT $(0,665)$ lebih besar dari pada $\alpha$ $(0,05)$ sehingga hipotesis lima ditolak. Tidak signifikannya hasil TAT yang diperoleh menunjukkan bahwa rasio TAT masih kurang memberikan sinyal positif bagi investasi yang dilakukan oleh investor. Menurut Hidayat (2009) meskipun informasi dari nilai TAT yang disajikan memberikan gambaran bagaimana aset yang dimiliki perusahaan dapat dikembalikan dari hasil aktivitasnya yaitu berupa pendapatan atau penjualan bersih pada perusahaan tersebut, namun hal ini menggambarkan bahwa perusahaan yang memiliki kinerja baik dalam memanfaatkan aset yang dimiliki tidak mampu menciptakan sentiment positif dari pasar terhadap penilaian kinerja perusahaan. Hal itu diduga dapat disebabkan karena penjualan yang tinggi belum tentu mencerminkan laba yang dihasilkan juga tinggi, sebab terkadang biaya yang dikeluarkan tidak sebanding lurus dengan pendapatan penjualan yang dihasilkan sehingga rasio TAT tidak cukup baik untuk digunakan dalam memprediksi return saham. Hasil penelitian ini mendukung penelitian yang dilakukan oleh Ulupui (2005), Hidayat (2009), dan Oktanugroho (2012) yang memeroleh hasil bahwa TAT tidak memiliki pengaruh yang signifikan terhadap return saham.

\section{Debt to Equity (DER)}

Rasio leverage yang diproksikan dengan DER tidak memiliki pengaruh negatif yang signifikan terhadap return saham pada perusahaan manufaktur, karena nilai signifikansi t $0,385>\alpha(0,05)$ sehingga hipotesis enam ditolak. Hal ini mengindikasikan bahwa nilai DER tidak menyebabkan perubahan return saham pada perusahaan manufaktur. Debt to Equity merupakan rasio utang yang secara umum mencerminkan tingkat kewajiban perusahaan dalam membayar hutanghutang jangka pendek maupun jangka panjangnya, sehingga beberapa pihak investor beranggapan bahwa DER yang besar dapat membebani keuangan perusahaan yang pada akhirnya dapat merugikan investor.

Namun kondisi yang berbeda juga dapat diperoleh dari investor dimana DER yang tinggi justru mencerminkan bahwa perusahaan sedang dalam pertumbuhan dimana perusahaan sangat membutuhkan pendanaan yang lebih cepat yang dapat diperoleh melalui kontrak dengan pihak ketiga (Kusumo, 2011). Adanya perbedaan pandangan ini menyebabkan rasio DER kurang baik untuk memprediksi return saham pada perusahaan manufaktur. Meskipun rasio DER yang dihasilkan tidak signifikan bukan berarti investor dapat mengabaikan rasio ini, karena proporsi utang yang tinggi akan menyebabkan risiko kebangkrutan usaha juga akan semakin besar. Hasil penelitian ini mendukung penelitian yang dilakukan oleh Ulupui (2005), Kusumo (2011), dan Saputra (2012) yang menyatakan bahwa DER tidak berpengaruh secara signifikan terhadap return saham. Namun hasil ini tidak sesuai dengan penelitian yang dilakukan oleh Oktanugroho (2012) yang menyetakan bahwa DER memiliki pengaruh yang signifikan terhadap return saham.

\section{Debt to Total Asset (DAR)}

Rasio leverage yang diproksikan dengan DAR tidak memiliki pengaruh yang signifikan terhadap return saham pada perusahaan manufaktur, karena nilai hipotesis tujuh ditolak. Hal ini mengindikasikan bahwa rasio utang yang diproksikan dengan DAR tidak menyebabkan perubahan terhadap return saham pada perusahaan manufaktur. Hal ini mendukung penelitian yang dilakukan oleh Oktanugroho (2012) dan tidak 
selaras dengan penelitian yang dilakukan oleh Pribawanti (2007) dan Widyawati (2012). Meskipun hasilnya tidak signifikan, bukan berarti investor dapat mengabaikan rasio utang suatu perusahaan, karena sering kali kondisi financial distress yang sedang dihadapi oleh perusahaan disebabkan tidak mampunya perusahaan dalam membayar utang. Proporsi utang yang tinggi akan menyebabkan fixed payment tinggi sehingga dapat menimbulkan adanya risiko kebangkrutan usaha (Natarsyah melalui Ulupui, 2005).

\section{Market to Book Ratio (MBV)}

$\begin{array}{lccc}\text { Rasio } & \text { Market } & \text { Value } & \text { yang } \\ \text { diproksikan } & \text { dengan } & \text { MBV } & \text { tidak } \\ \text { memiliki } & \text { pengaruh } & \text { positif } & \text { yang }\end{array}$
signifikan terhadap return saham pada perusahaan manufaktur, karena nilai

sehingga hipotesis delapan ditolak. Hasil pengujian tersebut mengindikasikan bahwa MBV tidak sepenuhnya memiliki daya tarik bagi investor sebagai gambaran ekspektasi terhadap kinerja perusahaan dalam menghasilkan return saham. Hal ini diduga karena adanya kondisi yang berlawanan dimana nilai MBV yang lebih besar menunjukkan bahwa perusahaan sedang mengalami pertumbuhan sehingga investor beranggapan bahwa hal tersebut akan memberikan keuntungan bagi investor dalam berinvestasi. Hal itu pada akhirnya akan meningkatkan harga saham sehingga return saham akan mengalami peningkatan.

Namun kondisi yang kontradiksi juga dapat terjadi pada nilai MBV, dimana rasio MBV yang tinggi justru tidak diinginkan oleh investor, karena MBV yang tinggi justru mencerminkan bahwa harga saham perusahaan dinilai terlalu tinggi dan tidak sebanding dengan nilai buku perusahaan yang dimiliki atau dalam hal ini harga sama mengalami overvalue. Harga saham yang overvalue cenderung akan dihindari oleh investor dalam melakukan investasi pada saham perusahaan tersebut. Kondisi yang berbeda seperti ini menyebabkan MBV tidak sepenuhnya memiliki daya tarik bagi investor. Hasil penelitian ini mendukung penelitian yang dilakukan oleh Hadi (2009) Khairi (2012) dan Indarwati (2012) yang menyatakan bahwa MBV tidak berpengaruh secara signifikan terhadap return saham.

\section{SIMPULAN, SARAN, DAN KETERBATASAN PENELITIAN Simpulan}

Berdasarkan pada hasil pembahasan penelitian yang telah diuraikan sebelumnya maka dapat disimpulkan bahwa ROA dan ROE memiliki pengaruh positif yang signifikan terhadap return saham perusahaan manufaktur, maka hipotesis pertama dan kedua diterima. Profit margin on sales tidak memiliki pengaruh yang singifikan terhadap return saham perusahaan manufaktur, maka hipotesis tiga ditolak. Rasio Profitabilitas yang baik digunakan sebagai proksi dalam pengukuran kinerja keuangan dalam memprediksi return saham adalah ROA dan ROE.Current ratio sebagai proksi dari rasio likuiditas tidak me miliki pengaruh yang signifikan terhadap return saham pada perusahaan manufaktur, sehingga hipotesis empat ditolak. Total asset turnover sebagai proksi dari rasio aktivitas tidak memiliki pengaruh yang signifikan terhadap return saham perusahaan manufaktur, sehingga hipotesis lima ditolak. Debt to Equity dan DAR sebagai proksi dari rasio leverage tidak memiliki pengaruh yang signifikan terhadap return saham perusahaan manufaktur, sehingga hipotesis enam dan tujuh ditolak. Market to book value sebagai proksi dari rasio market value tidak memiliki pengaruh yang signifikan terhadap return saham perusahaan manufaktur, sehingga hipotesis delapan ditolak. 


\section{Saran}

Bagi penelitian selanjutnya terdapat beberapa hal yang perlu diperhatikan diantarannya yaitu:

1. Kondisi makro ekonomi seperti inflasi, nilai tukar dapat digunakan sebagai variabel independen untuk memprediksi return saham pada perusahaan.

2. Perlu untuk memperhatikan penggunaan data lag pada variabel independen dalam memprediksi return saham yang diharapkan.

3. Penelitian selanjutnya akan lebih baik apabila dilakukan pembandingan dalam memprediksi return saham, yaitu dengan melakukan perbandingan antar sektor seperti sektor manufaktur dengan sektor jasa untuk mengetahui sektor mana yang memiliki prospek lebih baik dalam menghasilkan return saham, sehingga dapat bermanfaat bagi para investor dalam melakukan pengambilan keputusan.

\section{Keterbatasan Penelitian}

Peneliti menyadari bahwa masih banyak terdapat kelemahan yang ada dalam penelitian ini, yaitu:

1. Tidak adanya penggunaan data lag atau selisih waktu pada variabel independen untuk memprediksi return saham dalam penelitian ini.

2. Sampel yang digunakan masih terbatas pada asumsi dan kriteria tertentu yaitu hanya terbatas pada sektor manufaktur.

3. Masih banyaknya pengaruh lain diluar variabel dalam penelitian ini yang dapat digunakan untuk memprediksi return saham, yaitu sebesar $86,4 \%$ variabel indepeden lain yang dapat memengaruhi return saham.

\section{DAFTAR PUSTAKA}

Arista Desy, 2012, "Analisis Faktor-Faktor Yang Mempengaruhi Return Saham (Studi Kasus Pada Perusahaan Manufaktur Yang Go Public di BEI Periode 2005-2009)", Jurnal Ilmu
Manajemen dan Akuntansi Terapan, Volume 3 Nomor 1, STIE Totalwin, Semarang.

Astuti Subekti Puji, 2006, "Analisis Pengaruh Faktor-Faktor Fundamental, EVA, dan MVA Terhadap Return Saham (Studi Pada Perusahaan Manufaktur di Bursa Efek Jakarta Periode 2001-2003)", Tesis, Universitas Diponegoro, Semarang.

Brigham Eugene dan Houston Joel, 2010, Dasar - Dasar Manajemen Keuangan, Edisi 11, Salemba Empat, Jakarta.

Faried Asbi Rachman, 2008, "Analisis Pengaruh Faktor Fundamental dan Nilai Kapitalisasi Pasar Terhadap Return Saham Perusahaan Manufaktur di BEI Periode 2002-2006" Tesis. Universitas Diponegoro, Semarang.

Fidhayatin Septi K., 2012, "Analisis Nilai Perusahaan, Kinerja Perusahaan, dan Kesempatan Bertumbuh Perusahaan Terhadap Return Saham Pada Perusahaan Manufaktur yang Listing di BEI", The Indonesian Accounting Review Vol 2, STIE Perbanas, Surabaya.

Ghozali Imam, 2011, Aplikasi Analisis Multivariate Dengan Program SPSS, Badan Penerbit Universitas Diponegoro, Semarang.

Hadi Prasetya, 2009, "Analisis Pengaruh Leverage, Debt to Equity Ratio (DER), Return on Asset (ROA), Price Book Value (PBV), dan Price Earning Ratio (PER) Terhadap Return Saham, Studi Kasus Pada Perusahaan Manufaktur yang Terdaftar di BEI 2005 -

Maret, Solo.

Halim Abdul, 2005, Analisis Investasi, Salemba Empat, Jakarta. 
Hanafi Mamduh, Halim Abdul, 1996, Analisis Laporan Keuangan, Edisi Pertama, UPP-AMP YKPN, Yogyakarta.

Hardiningsih Pancawati, 2001, "Pengaruh Faktor Fundamental dan Risiko Ekonomi Terhadap Return Saham Perusahaan Di Bursa Efek Jakarta Studi Kasus Basic Industry dan Chemical", Tesis, Universitas Diponegoro, Semarang.

Hartono J., 2003, Teori Portofolio dan Analisis Investasi, Edisi Ketiga, BPFE, Yogyakarta.

Hidayat Taufik, 2009, "Pengaruh Rasio Keuangan Terhadap Return Saham Pada Perusahaan yang Terdaftar Di Bursa Efek Indonesia", Tesis, Universitas Sumatra Utara, Medan.

Indarwati Susan, 2012, "Pengaruh Earning Per Share (EPS), Debt to Equity Ratio (DER), Price Book Value (PBV), Return on Asset (ROA), Return on Equity (ROE) terhadap

Return Saham Studi Kasus Pada Farmasi Tbk yang terdaftar di BEI" Jurnal Ekonomi Manajemen, Universitas Gunadarma.

Jogiyanto, 2000, Teori Portofolio dan Analisis Investasi, BPFE, Yogyakarta.

Khairi Muhammad Shadiq, 2012, Analisis Pengaruh Karakteristik Perusahaan Return Saham Syariah Yang Tergabung di Jakarta Islamic Index Periode 2008-2011" Jurnal Ekonomi dan Bisnis, Universitas Brawijaya.

Kusumo Gian Ismoyo, 2011, "Analisis Pengaruh Rasio Keuangan Terhadap Return Saham Pada Perusahaan Non Bank", Jurnal Analisis Manajemen dan Bisnis,
Mangkunegara A., P., 2001, Manajemen Sumber Daya Manusia Perusahaan, Remaja Rosda Karya, Bandung.

Margaretha Farah, Damayanti Irma, 2008, "Pengaruh Price Earnings Ratio, Dividend Yield, dan Market to Book Value Terhadap Stock Return di Bursa Efek Indonesia", Jurna Bisnis dan Akuntansi, Volume 10 Nomor 3, Universitas Trisakti, Jakarta.

Munawir, 2002, Analisis Laporan Keuangan, Liberty, Yogyakarta.

Nugroho Inung Adi, 2009, "Analisis Pengaruh Informasi Fundamental Terhadap Return Saham (Studi Komparatif pada Sub Sektor Industri Otomotif Terhadap Sub Sektor Industri Textil Sepanjang Periode tahun 20032007 di BEI)", Tesis, Universitas Diponegoro, Semarang.

Nurhikmah Sitti, 2012, "Pengaruh Kinerja Keuangan Terhadap Return Saham (Studi Kasus Pada Industri Manufaktur yang Terdaftar di BEI)", Skripsi Strata I, Universitas Hasanuddin, Makassar.

Oktanugroho Ghita K., 2012, "Analisis Pengukuran Kinerja Keuangan terhadap Return Saham (Studi Pada Perusahaan Manufaktur yang Terdaftar di BEI 2008-2011)", Tesis, Universitas Ghajah Mada, Yogyakarta.

Pribawanti Tika M., 2007, "Analisis Pengaruh Rasio Keuangan Terhadap Total Return

Saham Pada Perusahaan Manufaktur yang Membagikan Deviden di Bursa Efek Indonesia", Skripsi Strata I, Universitas Negeri Semarang.

Inflasi, Nilai Tukar, ROA, DER, dan CR terhadap Return Saham (Studi Kasus Saham Industri Real Estate and Property yang Terdaftar di BEI 2003 - 
2006)", Tesis, Universitas Diponegoro, Semarang.

Saputra Angga, 2012, "Analisis Pengaruh Ukuran Perusahaan (Size), Return On Equity (ROE), Debt Equity Ratio (DER), Dan Erning Per Share (EPS) Terhadap Return Saham Pada Perusahaan Yang Tergabung Dalam Indeks Big Capitalization Yang Terdaftar Di Bursa Efek Indonesia (BEI)", Jurnal Akuntansi, Universitas Gunadarma.

Sari Fita Nur, 2012, “Analisis Pemngaruh DER, CR, ROE, dan TAT Terhadap Return Saham (Studi Pada Saham Indeks LQ45 Periode 2009 - 2011 Dan Investor Yang Terdaftar Pada Perusahaan Sekuritas Di Wilayah Semarang Periode 2012)", Skripsi, Universitas Diponegoro, Semarang.

Solechan Ahmad, 2009, "Pengaruh Manajemen Laba Dan Earning Terhadap Return Saham (Studi Empiris Pada Perusahaan Yang Go Public Di Bei Tahun 2003 - 2006)", Tesis, Universitas Diponegoro, Semarang.

Susilowati Yeye, 2011, "Reaksi Signal Rasio Profitabilitas Dan Rasio Solvabilitas Terhadap Return Saham Perusahaan" Jurnal Dinamika Keuangan dan Perbankan, Vol. 3 No. 1, Universitas Stikubank, Semarang.

Tandelilin Eduardus, 2001, Analisis Investasi dan Manajemen Portofolio Edisi Pertama, BPFE, Yogyakarta.

Ulupui IG et all., 2005, "Analisis Pengaruh Rasio Likuiditas, Leverage, Aktivitas, dan Profitabilitas terhadap Return Saham (Studi Pada Perusahaan Makanan dan Minuman Dengan Kategori Industri Barang Konsumsi Di BEJ)", Jurnal Akuntansi, Universitas Udayana.
Utomo Welly, 2007, "Analisis Pengaruh Beta dan Varian Return Saham Terhadap Return Saham (Studi pada Perusahaan LQ 45 di BEJ Periode Bulan Januari Tahun 2005 Sampai Desember 2005)", Tesis, Universitas Diponegoro, Semarang.

Widodo Saniman, 2007, "Analisis Pengaruh Rasio Aktivitas, Rasio profitabilitas, dan Rasio Pasar Terhadap Return Saham Syariah Dalam Kelompok Jakarta Islamic Index (JII) tahun 2003 - 2005", Tesis, Universitas Diponegoro, Semarang.

Widyawati Happy, 2012, "Pengaruh Ratio Profitabilitas Dan Leverage Terhadap Return Saham (Studi Kasus Pada Industri Automotive dan Alliend Product yang Listed di BEI)", Jurnal Akuntansi, Universitas Negeri Semarang.

Badan Pusat Statistik (BPS), Pertumbuhan Industri Manufaktur Indonesia,

http://www.bps.go.id/ Diakses pada tanggal 19 Mei 2013

Ikatan Akuntan Indonesia (IAI), Laporan Keuangan Interim PSAK No 3 Revisi 2010, www.iaiglobal.or.id Diakses pada tanggal 22 Agustus 2013. 